\title{
Effect of a peptide in cosmetic formulations for hair volume control
}

\author{
C. F. Cruz (iD, A. Ribeiro, M. Martins and A. Cavaco-Paulo \\ CEB - Centre of Biological Engineering, University of Minho, Braga 4710-057, Portugal
}

Received 24 April 2017, Accepted 9 July 2017

Keywords: climate control, hair, hair treatment, KP peptide, relative humidity

\begin{abstract}
OBJECTIVE: The capacity of hair to absorb water causes changes in its physical and cosmetic properties under different environmental conditions. Hence, the control of hair volume in variable relative humidity settings is an important topic in cosmetics. The behaviour of two types of hair, Caucasian and Asian, was studied regarding their volume change in different relative humidity conditions. The ability of a peptide as a hair volume treatment was evaluated in two climate control formulations.

METHODS: Tresses of the two types of hair were tested in two relative humidity $(\mathrm{RH})$ conditions: (A) variable relative humidity $(2 \mathrm{~h}$ $40 \% \mathrm{RH}$, followed by $2 \mathrm{~h} 90 \% \mathrm{RH}$ and $2 \mathrm{~h}$ of $40 \% \mathrm{RH}$ ), and (B) continuous high relative humidity $(90 \% \mathrm{RH}$ for $6 \mathrm{~h})$. Changes in the hair tress volume were assessed throughout time. Hair treated with two climate control formulations, with and without a peptide (KP peptide), were tested under the two relative humidity conditions.

RESULTS: Caucasian hair had a higher change in volume compared to the Asian hair in variable and high relative humidity conditions. The hair volume increase when subject to high air humidity, and it was lower with the incorporation of a peptide into climate control formulations.

CONCLUSION: Caucasian hair showed higher volume than Asian hair when submitted to both relative humidity conditions. The incorporation of the peptide into the climate control formulations, a base (mostly composed of water $\approx 94 \%$ ) and an ethanolic, was found to reduce the volume of Caucasian hair tresses. The presence of the peptide improved the hair volume change more than $60 \%$ in high relative humidity conditions.
\end{abstract}

\section{Résumé}

OBJECTIF: La capacité des cheveux à absorber l'eau provoque des changements de ses propriétés physiques et cosmétiques dans différentes conditions environnementales. Par conséquent, le contrôle du volume des cheveux dans des paramètres variables d'humidité relative est un sujet important dans la cosmétique. Le comportement de deux types de cheveux, de race blanche et asiatique, a été étudié en ce qui concerne leur variation de volume dans différentes conditions d'humidité relative. La capacité d'un peptide comme traitement du volume capillaire a été évaluée dans deux formulations de contrôle du climat.

Correspondence: Artur Cavaco-Paulo, CEB - Centre of Biological Engineering, University of Minho, 4710-057 Braga, Portugal; Tel.: +351-253604407; fax: +351 253604 429; e-mail: artur@deb.uminho.pt
MÉTHODES: Les mèche des deux types de cheveux ont été testées dans deux conditions d'humidité relative (HR): (A) humidité relative variable ( 2 heures $40 \% \mathrm{HR}$, suivie de 2 heures $90 \%$ HR et 2 heures de HR 40\%) et (B) humidité relative continue élevée (90\% HR pendant 6 heures). Les changements dans le volume de cheveux ont été évalués au fil du temps. Les cheveux traités avec deux formulations de lutte contre le climat, avec et sans peptide (peptide $\mathrm{KP}$ ), ont été testés dans les deux conditions d'humidité relative.

RÉSULTATS: Les cheveux caucasiens ont eu un changement de volume plus élevé par rapport aux cheveux asiatiques dans des conditions variables et à forte humidité relative. Le volume des cheveux augmente lorsqu'ils sont expose a une forte humidité de l'air, et ils sont plus faible avec l'incorporation d'un peptide dans des formulations de contrôle climatique.

CONCLUSION: Les cheveux caucasiens ont affiché un volume plus élevé que les cheveux asiatiques lorsqu'ils sont soumis aux deux conditions d'humidité relative. L'incorporation du peptide dans les formulations de contrôle climatique, une base (principalement composée d'eau $\approx 94 \%$ ) et une éthanolique, a permis de réduire le volume des mèches caucasiennes. La présence du peptide a amélioré le volume des cheveux en changeant plus de $60 \%$ dans des conditions d'humidité relative élevée.

\section{Introduction}

Hair's capacity to absorb large amounts of water is well-known. This property led to early air humidity sensors, the hair hygrometers [1]. Hence, water is a critical component of the hair fibre, affecting the hair form and several physical and cosmetic properties.

Human hair is a complex fibre, composed of three main components: cuticle, cortex and medulla [2-4]. Flattened, overlapping cuticle cells are the outer part of the hair with the function to protect it. The cuticle is subdivided into different layers: epicuticle, Alayer, B-layer and endocuticle. The epicuticle is the outermost layer, which is very hydrophobic and includes free lipids and 18-methyl eicosanoic acid (18-MEA). The A-layer is highly crosslinked providing structural strength and rigidity to the cuticle. The B-layer is slightly less cross-linked, and the endocuticle has low cystine content and low degree of cross-links [2-4]. The cortex is the major part of the hair fibre, made up of macrofibrils and microfibrils of keratin providing high tensile strength, and a matrix phase of keratin associated proteins, which work as a cement. The medulla is the innermost part of the hair and is constituted by vacuolated cells, when present [5].

It has been recognized that water plays an important role in hair cosmetic performance, and therefore acts as a critical factor, 
interfering with a wide variety of properties of the hair. Uptake of water is largely governed by chemical nature of hair. Despite the hydrophobicity of the cuticle, hair fibres are hygroscopic. The amount of water present in the hair fibre depends on the air relative humidity $(\mathrm{RH})$, temperature, $\mathrm{pH}$, solvents and overall hair fibre conditions such as hair damage or hair type [6,7]. The water absorption of the hair fibre is accompanied by a highly anisotropic swelling behaviour of hair, where hair swells up to $15 \%$ in diameter contrasting with less than $2 \%$ in fibre length [5]. The mechanism of water molecules binding to hair proteins depends on the relative humidity $(\mathrm{RH})$. Below 5\% $\mathrm{RH}$, there is a strong binding in hydrophilic sites of the hair proteins. Between $5 \%$ and $75 \% \mathrm{RH}$, weaker interactions occur between the water molecules and the proteins or with previously bonded water molecules, mainly by hydrogen bonds and salt bonds [4,7-9]. Above 75\% RH, also occurs the formation of water clusters [1].

Hair fibre swelling occurs mainly in non-keratinous proteins, such as in the cortical matrix and endocuticle [3,5]. Hair swelling can occur when any treatment causes instability of Coulombic interactions and destroys the hydrogen bond network $[5,10,11]$. As a result, water is able to slightly distort the structure of the keratin microfibrils, as swelling most likely occurs at the boundary between the cortical matrix and the microfibrils, and may also distort the structure of the organized lipids [1,5]. As the outer cuticle remains rigid, their scales are constrained to rise, overlapping with the next outer cuticle and leading to cuticle lift off [3]. This fact leads to increased friction between the fibres, static charge and electric resistance of the hair, followed by increased volume [12]. The shape and orientation of the cuticle cells determine the differential friction effect in hair $[5,13]$. In high relative humidity conditions, hair cortex and cuticle can absorb water. This water absorption affects the hydrogen and salt bonds between the protein molecules of the hair [4]. The process of water absorption happens fast, and the majority of the water is absorbed in the first minutes, mainly in very high relative humidity conditions [7].

Chemical changes in the hair fibre are introduced by the water through the breakage of non-covalent bonds. These chemical changes lead to modifications of hair physical properties, which cause reduced tensile properties, such as elasticity and break stress, and influences the static charge and electric resistance of the hair $[3,5,14]$. The control of these properties in high and variable relative humidity conditions is, therefore, an important property of cosmetic products. This study aimed to understand the behaviour of different types of hair under high relative humidity conditions and controlled temperature. We also explore the effect of a peptide in different climate control formulations in the hair in the same conditions.

Proteins and peptides have been used in hair, due to their ability to improve smoothness, lustre, elasticity and for damage protection. Due to their chemical composition and numerous binding sites, proteins have a high chemical affinity to hair keratin and ability to be absorbed on the hair surface and even penetrate into hair cortex [15-20]. Generally, proteins are able to improve tensile strength and elasticity of the hair, protecting from adverse effects of the chemical treatments [15-23]. Keratin derivatives in cosmetics are generally well accepted. They are considered to have higher substantivity to hair keratin than other animal and vegetable proteins, such as collagen, casein, fibroin and wheat derivatives [24]. Proteins and derivatives, such as peptides or hydrolysed proteins, have been used to improve cosmetic characteristics, including conditioning properties, repair and protection [15,16,25-31]. Some proteins
Table I Climate Control formulations components

\section{Climate control}

formulation

Components of the formulation

$\begin{array}{ll}\text { Base formulation } & \text { Water }(93.5 \%) \\ & \text { Hydroxyethylcellulose }(<1 \%) \\ & \text { Triethanolamine }(<1 \%) \\ & \text { Copolymer of polydi-methylsiloxane } \\ \text { and polyoxyalkylene ether }(<1 \%) & \text { Vegetable oil }(<1 \%) \\ & \text { Polyquaternium-70 }(<1 \%) \\ & \text { Propylene glycol }(<1 \%) \\ & \text { Diazolidinyl urea }(<1 \%) \\ & \text { lodopropynyl butylcarbamate }(<1 \%) \\ & \text { Panthenol }(<1 \%) \\ & \text { Tween } 20(<1 \%) \\ & \text { Fragrance }(<1 \%) \\ & \text { Water }(72.3 \%) \\ \text { Denaturated alcohol }(20 \%) & \text { C10-30 Alkyl Acrylate Crosspolymer }(<1 \%) \\ \text { Ethanolic formulation } & \text { Propylene glycol }(<1 \%) \\ & \text { Benzyl alcohol }(<1 \%) \\ \text { Triethanolamine }(<1 \%) & \text { Tween } 20(<1 \%) \\ \text { Fragrance }(<1 \%) \\ \end{array}$

derivatives have also been used for hair fibre water-retention [32-34].

The KP peptide was developed based on the sequence of a human hair cuticular keratin and was characterized regarding its restorative properties on damaged hair $[15,16]$. KP was incorporated into two formulations, base and ethanolic climate control formulations, to demonstrate its ability to improve moisture resistance.

\section{Experimental procedures}

\section{Materials}

Natural virgin hair tresses were provided by International Hair Importers \& Products Inc. (New York). The climate control formulations were prepared based on commercial formulations. Base (mostly composed of water) and ethanolic climate control formulations are described in Table I. The peptide used in this study, KP, was synthesized by JPT Peptide Technologies GmbH. This peptide has thirteen amino acids in its sequence. All chemicals were purchased from Sigma-Aldrich (Madrid, Spain), except when stated otherwise.

\section{Methods}

Preparation of hair tresses

Two different types of hair were used as follows: Caucasian and Asian. Tresses of each type of hair with approximately $1.5 \mathrm{~g}$ and $15 \mathrm{~cm}$ in length were washed with a common commercial shampoo slightly acidic to neutral $(\mathrm{pH} \approx 6)$, gently dried and kept under the same conditions before humidity assessment treatments.

\section{Treatments with climate control formulations}

Caucasian hair was selected to test different climate control formulations with the incorporation of the KP peptide. Two different 
(a)

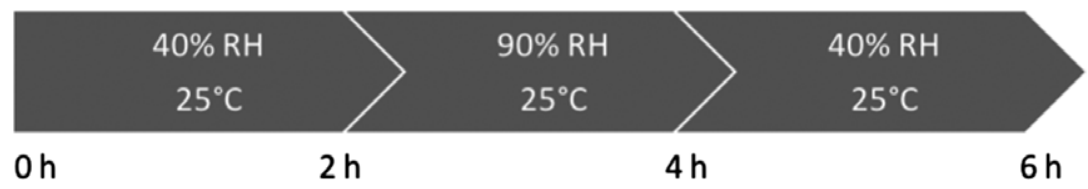

(b)

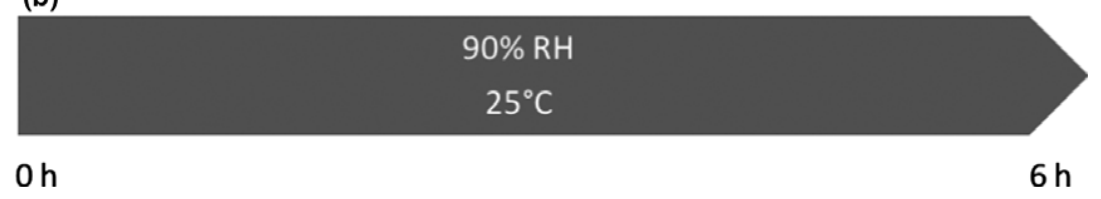

Figure 1 Scheme of the humidity conditions for all types of hair samples: (A) variation from medium to high relative humidity conditions, and (B) high relative humidity conditions.

climate control products were tested, without and with $0.01 \%$ (w/ v) of the KP peptide: base climate control and ethanolic climate control. A volume of $0.5 \mathrm{~mL}$ of each product was applied homogeneously in the hair tresses ten minutes prior to the exposition to the controlled environment.

Evaluation of KP peptide binding affinity towards hair keratin Human hair keratin was extracted from Caucasian hair following an adapted procedure from previous studies $[35,36]$. The hair was washed with a solution of $0.5 \%$ sodium dodecyl sulphate (SDS) with constant agitation for $1 \mathrm{~h}$ and dried at room temperature. External and internal hair lipid contents were removed by immersion, in constant agitation, with ethanol $1: 20$ for $2 \mathrm{~h}$ and methanol/chloroform $1: 2$ for $24 \mathrm{~h}$. Then, the hair was washed three times with water to completely remove the solvents and let dry at room temperature. The hair was cut into very small pieces and incubated in a solution with a ratio $1: 10$ containing $8 \mathrm{M}$ urea, $0.2 \mathrm{M}$ SDS and $0.5 \mathrm{M}$ sodium metabisulphite. The mixture was heated to $100^{\circ} \mathrm{C}$ for 30 minutes and left at $37^{\circ} \mathrm{C}$ for $24 \mathrm{~h}$ with constant agitation, for better desegregation of the hair fibres. Finally, the mixture was filtered through a glass filter and dialysed against distilled water using cellulose tubing molecular weight cutoff $12-14 \mathrm{kDa}$.

The extracted keratin $\left(160 \mathrm{mg} \mathrm{L}^{-1}\right)$ was incubated with $0.05 \mathrm{mM}$ of $\mathrm{KP}$ for $2 \mathrm{~h}$ at $24^{\circ} \mathrm{C}$ in a shaking bath, in a ratio $1: 1$. The peptide not linked to the extracted keratin was removed by dialysis against phosphate buffer $\mathrm{pH} 7$, using a cellulose membrane with 12-14 kDa cut-off for 2 days. The experiment was performed in triplicate.

\section{Volume assessment of hair tresses in different relative humidity conditions}

The relative humidity assessment was performed for the different types of hair and for Caucasian hair treated with the climate control formulations. The relative humidity tests were performed in a constant climate chamber Binder KBF 115 at $25^{\circ} \mathrm{C}$ and with a variation of relative humidity ( $2 \mathrm{~h}$ at $40 \% \mathrm{RH}$, followed by $2 \mathrm{~h}$ at $90 \% \mathrm{RH}$ and $2 \mathrm{~h}$ at $40 \% \mathrm{RH})$. This test allows the assessment of the variation from medium to high relative humidity conditions as well as the ability of the products to provide moisture resistance in the different environments, Fig. 1. The hair tresses were also tested in high relative humidity conditions ( $6 \mathrm{~h}$ at $90 \% \mathrm{RH})$. The procedure was adapted from TRI Princeton Educational Center [37]. The hair tresses were hung in a support in the constant climate chamber once the initial conditions stabilized. The hair samples were monitored over time. Readings on changes in hair volume were obtained throughout the measurement of the width of the hair tress in centimetres at the same length. For hair samples submitted to the variation from medium to high relative humidity, these measurements were performed every hour and in the first 10 and $15 \mathrm{~min}$ of each two hours $(2 \mathrm{~h} 10 \mathrm{~min}, 2 \mathrm{~h}$ $15 \mathrm{~min}, 4 \mathrm{~h} 10 \mathrm{~min}, 4 \mathrm{~h} 15 \mathrm{~min}$ ). For the continuous high $\mathrm{RH}$ conditions, the measurements were performed at $0 \mathrm{~h}, 15 \mathrm{~min}$, $30 \mathrm{~min}, 1 \mathrm{~h}$ and $30 \mathrm{~min}, 2 \mathrm{~h}$ and $30 \mathrm{~min}, 3 \mathrm{~h}, 4 \mathrm{~h}, 5 \mathrm{~h}$, and $6 \mathrm{~h}$. The variation in hair tress volume was determined using the equation:

\section{Hair tress volume change (\%) \\ $=\frac{\text { Hair tress volume }_{\text {point }}-\text { Minimum }(\text { Hair tress volume })}{\text { Maximum }(\text { Hair tress volume })-\text { Minimum }(\text { Hair tress volume })} \times 100$}

where 'Hair tress volume point' corresponds to the volume of the hair tress at each time point, 'Minimum (Hair tress volume)' corresponds to the minimum value registered, 'Maximum (Hair tress volume)' corresponds to the higher volume change registered in each type of hair. The evolution of hair tress aspect over time was then analysed through image analysis. Each hair tress condition was tested and measured in triplicate.

Statistical analyses were performed with SPSS, using the oneway ANOVA test, followed by the Tukey's post-hoc test, for the end time points of each stage ( $6 \mathrm{~h}$ of continuous $90 \% \mathrm{RH} ; 2 \mathrm{~h}, 4 \mathrm{~h}$ and $6 \mathrm{~h}$ of variable RH). $P$-values $\leq 0.05$ were considered statistically significant.

\section{Thermogravimetric behaviour of the hair samples}

Before assays, the hair samples were kept in a desiccator for at least $3 \mathrm{~h}$. Ten minutes prior to the exposition to $1 \mathrm{~h}$ of $90 \% \mathrm{RH}$ at $25^{\circ} \mathrm{C}$, hair samples were treated with the climate control formulations, as previously described. The moisture content of the hair tresses was assessed by thermogravimetric analysis (TGA) in a PerkinElmer TGA 4000 equipment. Hair samples (10-14 mg) were kept at $20^{\circ} \mathrm{C}$ for one minute, and then the temperature was increased from 20 to $180^{\circ} \mathrm{C}$ at $10^{\circ} \mathrm{C}$ per minute. The measurements were conducted in an atmosphere of nitrogen with a purge 

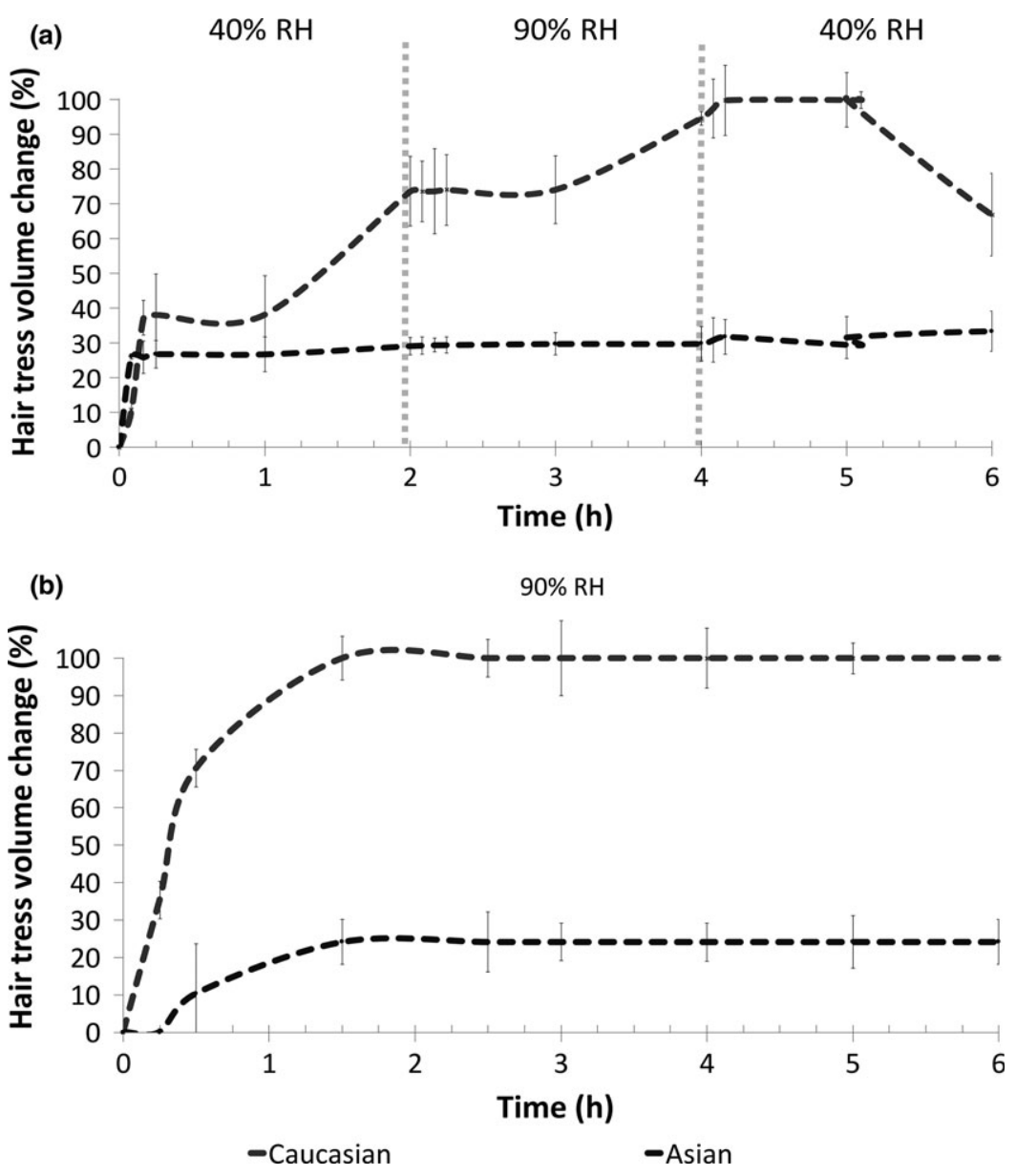

Figure 2 Percentage of volume change of hair tresses after exposure at different relative humidity conditions: (A): $40 \%$ RH in the first 2 h, $90 \%$ RH from 2 to $4 \mathrm{~h}$ and $40 \% \mathrm{RH}$ from 4 to $6 \mathrm{~h}$ and (B) $90 \% \mathrm{RH}$ for $6 \mathrm{~h}$. The data represents the average for each condition (triplicates) and the error bars represents the standard deviation.

of $19.8 \mathrm{~mL} \mathrm{~min}-1$ and a pressure of 3 bar. All measurements were performed in duplicate.

\section{Results and discussion}

Volume assessment of Caucasian and Asian hair in different relative humidity conditions

Caucasian and Asian hair, despite their similar constitution, have different properties, either mechanical or resistance to hair cosmetic treatments. These hair types were investigated regarding their resistance to volume change with a variation from medium to high relative humidity and continuous high relative humidity conditions. Quantitative and qualitative results are shown in Figs. 2 and 3.

The variation of relative humidity in Fig. 2 showed that Asian hair reached a plateau of hair tress volume at approximately 30\% of volume change, even after $2 \mathrm{~h}$ at $40 \% \mathrm{RH}$. Caucasian hair had a more variable volume change through the $\mathrm{RH}$ variation. Hair tress volume increased after exposition to $40 \% \mathrm{RH}$ environment, increased even more after $2 \mathrm{~h}$ at $90 \% \mathrm{RH}$ and decreased after $1 \mathrm{~h}$ at $40 \%$ RH. Both types of hair, Caucasian and Asian, were statistically different at the end of the $90 \%$ RH stage.

When submitted to continuous high relative humidity (90\%) the Caucasian hair tress suffered a higher volume change than the Asian hair. The Caucasian hair showed a statistically significant different volume increase. This volume increase was especially fast in the first hour of exposure. The Caucasian hair showed an increase of almost 90\%, whereas Asian hair exhibited a volume change of $24 \%$.

It is clear from Figs. 2 and 3 that Caucasian hair reached a higher volume change in the high $\mathrm{RH}$ condition than in the variable $\mathrm{RH}$ condition. The opposite occurs for Asian hair, which showed higher increase volume change in the variable RH condition.

However, the composition of amino acids and lipids is similar the behaviour of each type of hair is in accordance with previous studies which indicate that hairs' volume change is dependent on hair fibre geometry $[5,38,39]$. The friction coefficient is typically higher in swelled hair, being affected by several factors, namely by the relative humidity. When the endocuticle swells, it becomes more brittle and the cuticle scales lift. 
Time $=0 \mathrm{~h}, \mathbf{9 0 \%} \mathbf{R H}$

Caucasian

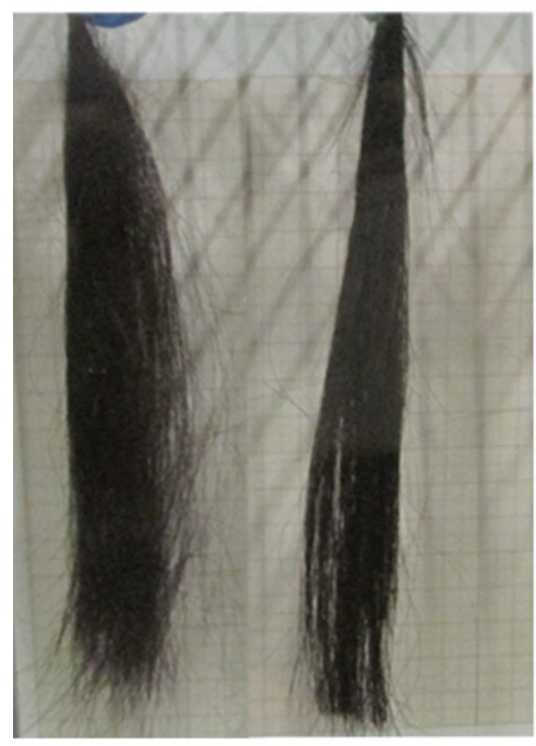

Time $=6 \mathrm{~h}, \mathbf{9 0 \%} \mathbf{R H}$

Caucasian Asian

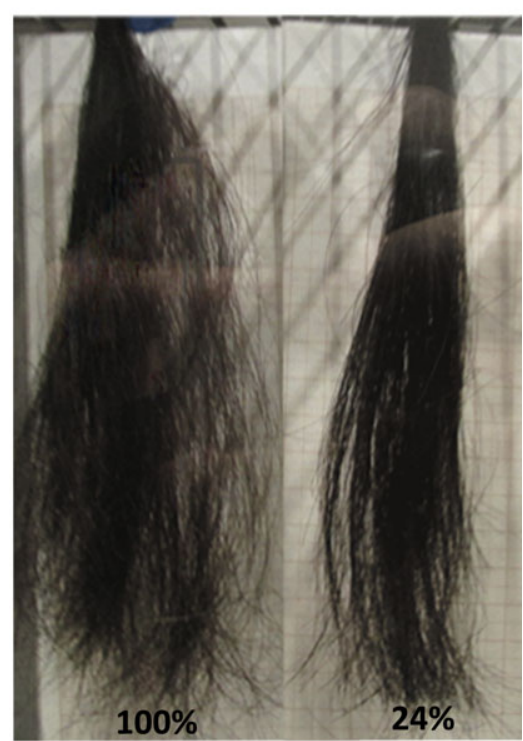

Volume change (\%)

Figure 3 Images of hair tresses at the beginning $(0 \mathrm{~h})$ and after $6 \mathrm{~h}$ of high relative humidity exposure (90\% RH). The values indicated correspond to the volume change, in percentage. Hair tresses are from left to right: Caucasian and Asian hair.

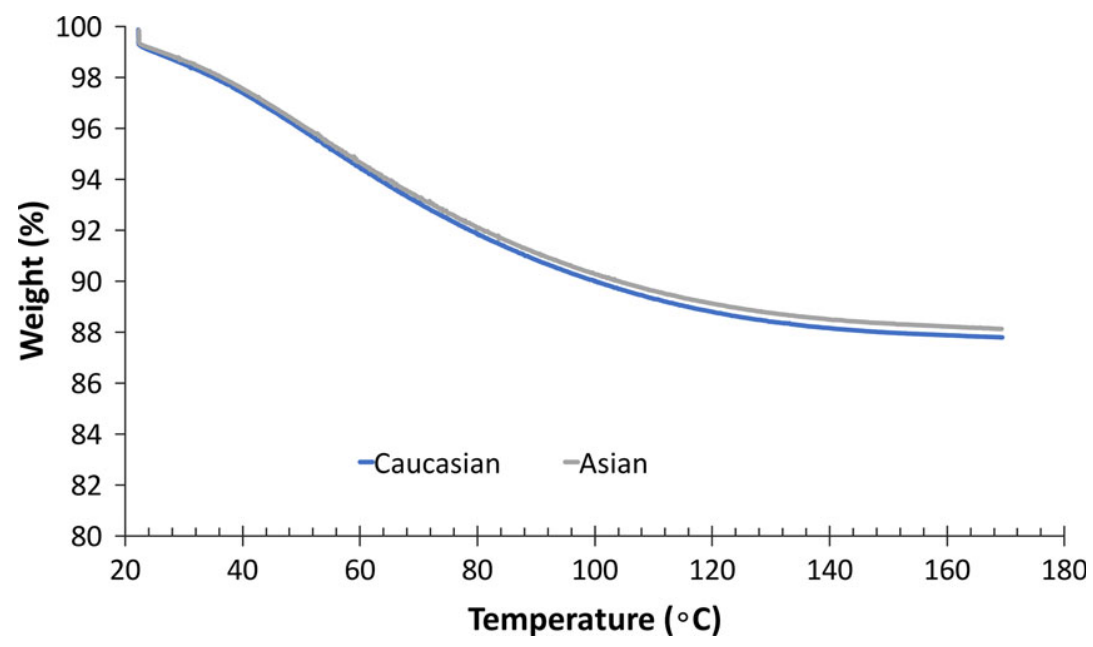

Figure 4 Hair weight loss of virgin Caucasian and Asian hair after exposure to $90 \%$ RH, determined by TGA.

Caucasian and Asian hair have a similar radial swelling [38], also corroborated by the water loss determined by thermogravimetric experiments after exposure to $90 \%$ RH, Fig. 4. Both types of hair have similar water absorption; however, a variable hair volume change occurred. The differences in the hair fibre characteristics could influence their behaviour. The hair surface and the endocuticle of the Caucasian hair have lower hardness and elastic modulus than Asian hair [3,4], which may lead to an increased extension, higher cuticle scales lift and higher hair tress volume $[3,4]$. As the Caucasian hair presented the highest volume change for both RH conditions, it was used to study the effect of climate control formulations with and without the KP peptide.

\section{Volume assessment of hair treated with climate control} formulations

The Caucasian hair was selected to test the effect of climate control formulations due to its higher variation in volume when exposed to different humidity conditions. Two different climate control formulations were used in the same conditions previously reported. 

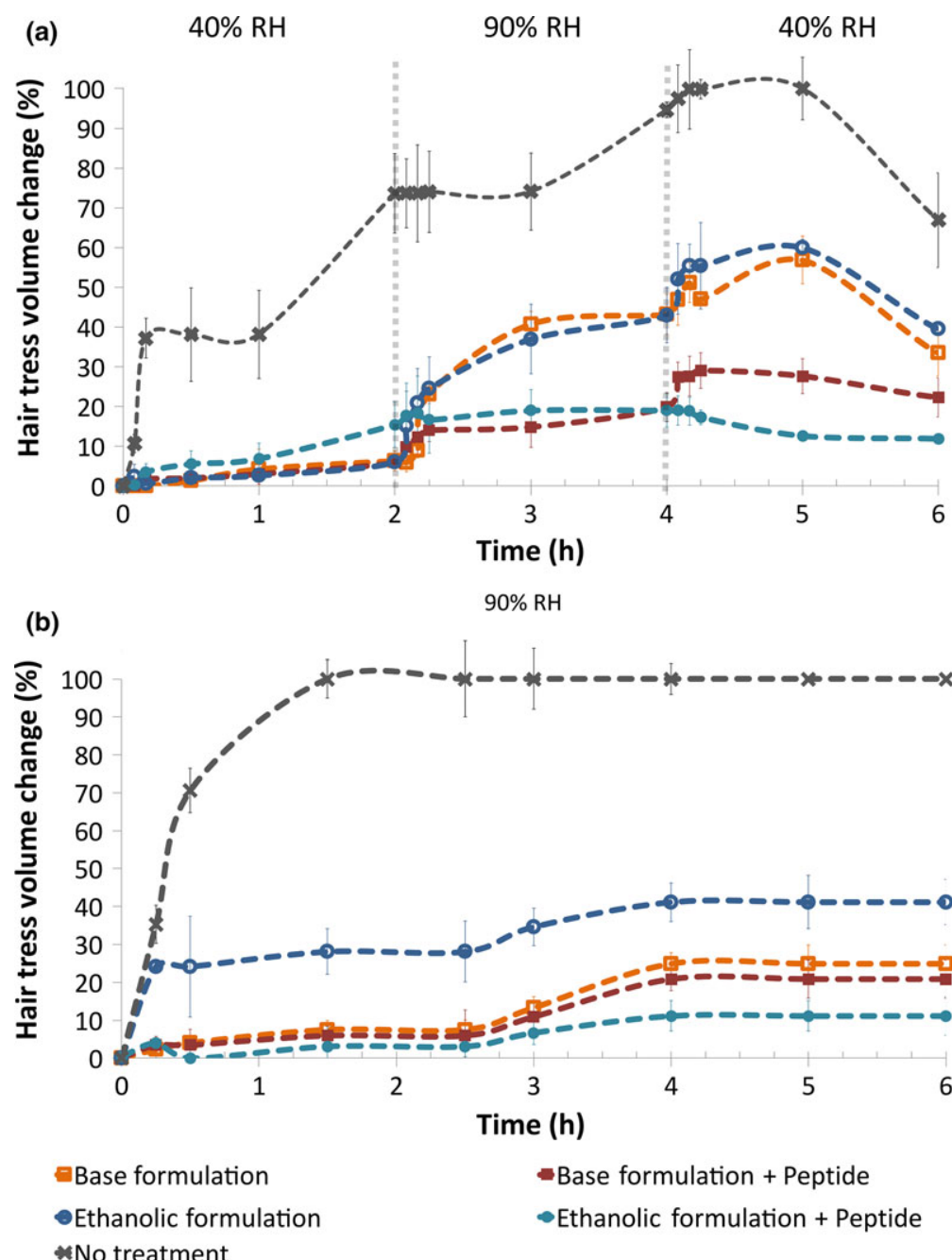

Figure 5 Percentage of volume change of Caucasian hair tresses at different relative humidity conditions after climate control treatments. The relative humidity conditions are as follows: (A) 40\% RH in the first $2 \mathrm{~h}, 90 \% \mathrm{RH}$ from 2 to $4 \mathrm{~h}$ and $40 \% \mathrm{RH}$ from 4 to $6 \mathrm{~h}$ and (B) $90 \% \mathrm{RH}$ for $6 \mathrm{~h}$. The data represents the average for each condition (triplicates), and the error bars represent the standard deviation.

Figs. 5 and 6 show, respectively, a quantitative and qualitative profile of the hair tresses treated with the climate control formulations in the presence and absence of the KP peptide. Table II indicates the statistical analyses of the quantitative hair volume changes in the different environment conditions. It was verified. The morphological features of the hair samples were observed by scanning electron microscopy (SEM) (Figure S1- Supplementary results). It was observed that all samples before and after treatment with climate control formulations have not morphological changes maintaining the integrity of hair surface with closed cuticles

Peptides have been recognized as having affinity towards hair surface, ability to restore damaged cuticles, inherent resilience and pliability and some proteins derivatives are used for hair fibre water-retention [16,32-34,40]. Previous studies have demonstrated KP peptide ability to recover the mechanical and thermal properties of over-bleached blond hair and strengthen weakened relaxed African hair $[15,16]$. As KP is based on a human hair cuticular keratin protein, it may have more affinity to the hair cuticular structure, improving hair resistance to water absorption. The KP peptide was studied regarding its affinity to hair keratin extracted from human hair. After dialysis, approximately $88 \%$ of KP peptide was bound to the extracted hair keratin. These results supported the high affinity of the KP peptide to the hair keratin. Additionally, KP peptide has a hydrophobic character, which in combination with it properties mentioned above, could highly contributes to improve the resistance of the moisture diffusion into the hair fibre.

The impact of KP peptide in the improvement of climate control formulations as hair volume control was studied. Analysing Figs. 5, 6 and Table II, the effect of the climate control formulations and the KP peptide was evident for all tested conditions. The hair treatment with the climate control formulations containing the peptide was statistical significantly different from the hair without treatment, for all conditions and stages.

For medium relative humidity conditions $(40 \% \mathrm{RH})$, there was an increase of $7 \%$ on hair tresses volume for all formulations, 

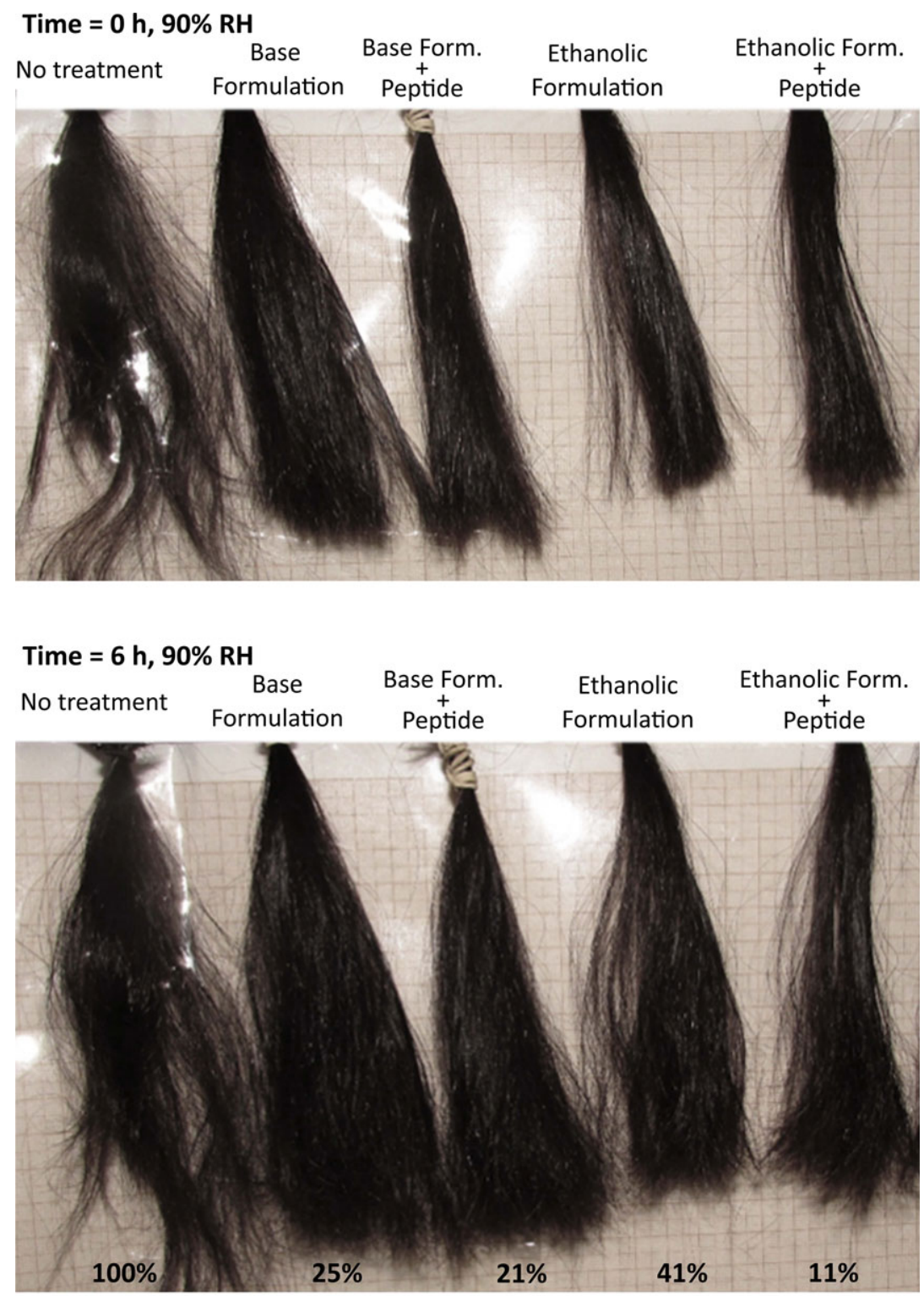

Volume change (\%)

Figure 6 Images of Caucasian hair tresses at the beginning of the test $(0 \mathrm{~h})$ and after $6 \mathrm{~h}$ at $90 \% \mathrm{RH}$.

except for the ethanolic formulation with an increase of $15 \%$ on hair volume (Fig. 5A). For the same RH, the samples with no treatment had a volume change of approximately $70 \%$, statistically different from every hair sample treated with the climate control formulations. Hence, the climate control treatment, even without the KP peptide, was enough to avoid an increase in hair volume. When the RH was increased to $90 \%$ the effect of the KP was more evident, the variation of volume was $60 \%$ lower compared to hair without treatment. The volume change of hair tresses treated with the formulations with peptide was lower when compared to the hair tresses without treatment or treated with formulations without peptide. At this stage, the hair tresses treated with the formulations containing the KP peptide suffered a statistically significant volume change when compared to the hair treated with the climate control formulations without peptide. These changes were inferior to $20 \%$ when treated with formulations containing KP peptide and around $40 \%$ for hair tresses treated with the climate control formulations without peptide for base and ethanolic formulation. In the third stage, when the $\mathrm{RH}$ was again $40 \%$, all hair samples decreased their volume. At this stage, only the hair treated with climate control formulations containing the KP peptide were statistically different from the hair without treatment.

The effect of KP peptide in hair volume control was more pronounced when the hair samples were exposed to continuous relative humidity of $90 \%$ (Fig. 5A). For this RH condition, the hair 
Table II $P$-value of statistical significant differences $(P \leq 0.05$, determined by one-way ANOVA test, followed by Tukey's post-hoc test) of hair volume change after treatment with the climate control formulations in $90 \%$ RH and variable RH conditions, at the final measurement of each stage. NT stands for no treatment, $\mathrm{BF}$ for base formulation, BF $+\mathrm{KP}$ for base formulation containing KP peptide, EF for ethanolic formulation and $\mathrm{EF}+\mathrm{KP}$ for ethanolic formulation containing KP peptide

\begin{tabular}{|c|c|c|c|c|}
\hline$P$-value of differences sta & $\begin{array}{l}\text { ificant } \\
\text { Variable: } 40 \% \text { RH } \\
\text { (1st stage) }\end{array}$ & $\begin{array}{l}\text { Variable: } 90 \% \text { RH } \\
\text { (2nd stage) }\end{array}$ & $\begin{array}{l}\text { Variable: } 40 \% \mathrm{RH} \\
\text { (3rd stage) }\end{array}$ & $\begin{array}{l}\text { Continuous } \\
90 \% \mathrm{RH}\end{array}$ \\
\hline No treatment (NT) & $\begin{array}{l}0.000 \text { for } \mathrm{BF} \\
0.000 \text { for } \mathrm{BF}+\mathrm{KP} \\
0.000 \text { for } \mathrm{EF} \\
0.000 \text { for } \mathrm{EF}+\mathrm{KP}\end{array}$ & $\begin{array}{l}0.001 \text { for } \mathrm{BF} \\
0.000 \text { for } \mathrm{BF}+\mathrm{KP} \\
0.001 \text { for } \mathrm{EF} \\
0.000 \text { for } \mathrm{EF}+\mathrm{KP}\end{array}$ & $\begin{array}{l}0.005 \text { for } \mathrm{BF}+\mathrm{KP} \\
0.000 \text { for } \mathrm{EF}+\mathrm{KP}\end{array}$ & $\begin{array}{l}0.000 \text { for } B F \\
0.000 \text { for } B F+K P \\
0.000 \text { for } E F \\
0.000 \text { for } E F+K P\end{array}$ \\
\hline Base Formulation (BF) & 0.000 for $\mathrm{NT}$ & $\begin{array}{l}0.001 \text { for } \mathrm{NT} \\
0.001 \text { for } \mathrm{BF}+\mathrm{KP} \\
0.001 \text { for } \mathrm{EF}+\mathrm{KP}\end{array}$ & 0.013 for $\mathrm{EF}+\mathrm{KP}$ & 0.000 for $\mathrm{NT}$ \\
\hline $\begin{array}{r}\text { Base Formulation }+ \\
\text { Peptide }(\mathrm{BF}+\mathrm{KP})\end{array}$ & 0.000 for $\mathrm{NT}$ & $\begin{array}{l}0.000 \text { for } \mathrm{NT} \\
0.001 \text { for } \mathrm{BF} \\
0.001 \text { for } \mathrm{EF}\end{array}$ & $\begin{array}{l}0.005 \text { for } \mathrm{NT} \\
0.047 \text { for } \mathrm{EF}\end{array}$ & 0.000 for $\mathrm{NT}$ \\
\hline Ethanolic Formulation (EF) & 0.000 for $\mathrm{NT}$ & $\begin{array}{l}0.001 \text { for } \mathrm{NT} \\
0.001 \text { for } \mathrm{BF}+\mathrm{KP} \\
0.001 \text { for } \mathrm{EF}+\mathrm{KP}\end{array}$ & $\begin{array}{l}0.047 \text { for } \mathrm{BF}+\mathrm{KP} \\
0.002 \text { for } \mathrm{EF}+\mathrm{KP}\end{array}$ & 0.041 for $E F+K P$ \\
\hline $\begin{array}{l}\text { Ethanolic Formulation + } \\
\text { Peptide }(E F+K P)\end{array}$ & 0.000 for $N T$ & $\begin{array}{l}0.000 \text { for } \mathrm{NT} \\
0.001 \text { for } \mathrm{BF} \\
0.001 \text { for } \mathrm{EF}\end{array}$ & $\begin{array}{l}0.000 \text { for } \mathrm{NT} \\
0.013 \text { for } \mathrm{BF} \\
0.002 \text { for } \mathrm{EF}\end{array}$ & $\begin{array}{l}0.000 \text { for } \mathrm{NT} \\
0.041 \text { for } \mathrm{EF}\end{array}$ \\
\hline
\end{tabular}

tresses treated with the climate control formulations, with and without the KP peptide, had a volume change inferior to $40 \%$, all statistically different. Comparing the hair volume changes relatively to the conditions of relative humidity was observed that the variable RH condition contributed for a higher increment of hair volume.

Regarding the formulations containing the KP peptide, the ethanolic formulation had a strong effect in controlling the volume changes of hair tresses, mainly in the continuous $\mathrm{RH}$ condition.
The volume control of damaged hair could be even more evident than virgin hair once it has damaged cuticles (open cuticles) and has less hydrophobicity. The results showed that the presence of KP peptide in the base formulation (without alcohol) was not statistically different in hair volume change. The volume change of hair treated with ethanolic formulation with and without the KP peptide was statistically different. The presence of the alcohol in the ethanolic formulation most likely promoted a better penetration of the peptide due to hair swelling induced by the alcohol [41].

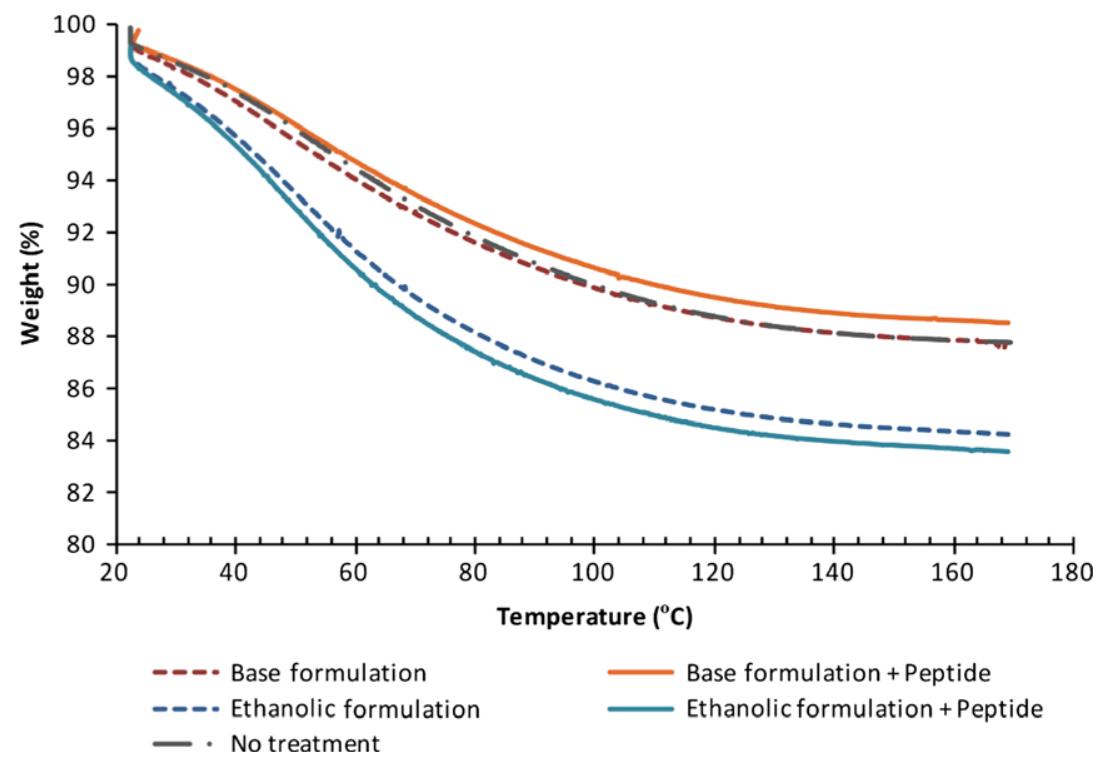

Figure 7 Hair weight loss of hair treated with the climate control formulations, determined by TGA. 
Climate control formulations are themselves able to adhere to the hair, avoiding further pathways of water molecules to soak the inner parts of the hair.

The ability of peptides to increase hair moisturization was referred by some studies [25,42]. Previous studies have also demonstrated KP peptide ability to recover the mechanical and thermal properties of over-bleached blond hair and strengthen weakened relaxed African hair $[15,16]$. Combining these evidences with the affinity to extracted hair keratin, KP peptide ability to bind to hair proteins was established. KP peptide has $38 \%$ of hydrophobic amino acid residues on its sequence, and presents several hydrophobic and hydrogen interactions, contributing to the overall binding force between peptide-hair interactions [2,12,20,22,23]. It hydrophobicity could favour further adherence of the climate control formulations to the hair cuticle, and eventually reduce the moisture diffusion and hair fibre water content [25].

Other applications of peptides for a similar use typically combine proteins hydrolysates and amino acids. However, to the knowledge of the authors, most of these proteins are used for hair moisturizing purposes rather than to avoid hair volume change in extreme air humidity conditions [32,34]. In this study, a synthetic peptide analogous to keratin proteins was used. This peptide has proved to penetrate into the hair fibre, and recover hair fibre mechanical and thermal resistance after severe hair damage $[15,16]$.

\section{Thermogravimetric behaviour of the treated hair with the formulations}

The water content of the hair treated with the climate control formulations was evaluated by thermogravimetric analysis, Fig. 7. No significant differences were found in water content between the hair samples treated with the base formulation, with and without the peptide, and the non-treated hair samples. An external water loss approximately of $10 \%$ was measured for all these samples. For the hair treated with the ethanolic formulation, with and without the KP peptide, the percentage of water loss was slightly higher $(\sim 15 \%)$. The ethanolic formulation has itself a strong interaction with the hair structure, and the presence of ethanol is predominant to increase hair swelling [42]. The thermogravimetric results corroborate this hypothesis as it is clear from Fig. 7 that with the ethanolic climate control formulation the absorption of water from the atmosphere is prevented. As the hair fibre easily absorbs the formulations (with high water content), the TGA results for base and no treatment samples, are quite similar. Thus, the slight hydrophobicity from ethanolic formulation seems to be the main factor to prevent the air moisture absorption by the hair fibre.

\section{Conclusions}

The relative humidity assessment in variable and continuous high conditions was crucial to provide insights about the behaviour of the different types of hair and the effect of climate control formulations with and without the KP peptide. The relative humidity assessment of different types of hair showed an evident hair tress volume change, especially for Caucasian hair. Despite similar radial swelling between both types of hair, the inferior hardness of the inner cuticle of Caucasian hair is proposed to be responsible for that volume change. Caucasian hair was selected for further investigation about the effect of KP peptide incorporated into climate control formulations. It was demonstrated that the use of KP peptide decreased the volume change of Caucasian hair, especially for the ethanolic formulation in continuous $\mathrm{RH}$ condition $(90 \% \mathrm{RH})$ and in $\mathrm{RH}$ variable condition (90\% RH followed by $40 \% \mathrm{RH})$. KP peptide was evidenced as an excellent agent to reduce the effect of volume change at high RH conditions while binding to hair keratin and keratin-associate proteins, through the climate control formulations.

The development of new formulations to prevents hair volume change when exposed to high relative humidity is essential in hair cosmetics. Herein, we give a strong input in this important cosmetic issue. The results clearly showed that the ethanolic climate control formulation containing the KP peptide had the ability to control hair volume changes, supporting the role of KP peptide as volume control agent.

\section{Acknowledgements}

We thank the Industry and Processes Laboratory (LIP) from Centre of Biological Engineering (CEB) for allowing the use of the climate chamber Binder KBF 115.

This work was supported by the Portuguese Foundation for Science and Technology (FCT) under the scope of the strategic funding of UID/BIO/04469/2013 unit and COMPETE 2020 (POCI01-0145-FEDER-006684) and under the Project RECI/BBB-EBI/ 0179/2012 (FCOMP-01-0124-FEDER-027462). This study was also supported by BioTecNorte operation (NORTE-01-0145-FEDER000004) funded by the European Regional Development Fund under the scope of Norte2020 - Programa Operacional Regional do Norte. Célia F. Cruz and Artur Ribeiro thank FCT for SFRH/BD/ $100927 / 2014$ and SFRH/BPD/98388/2013 grants, respectively.

\section{References}

1. Bouillon, C. and Wilkinson, J., editors. The Science of Hair Care. 2nd ed. Taylor \& Francis, Boca Raton (2015).

2. Wolfram, L.J. Human hair: a unique physicochemical composite. J. Am. Acad. Dermatol. 48, 106-114 (2003).

3. Seshadri, I.P. and Bhushan, B. Effect of ethnicity and treatments on in situ tensile response and morphological changes of human hair characterized by atomic force microscopy. Acta Mater. 56, 3585-3597 (2008).
4. Bhushan, B. Nanoscale characterization of human hair and hair conditioners. Prog. Mater Sci. 53, 585-710 (2008).

5. Robbins, C.R. Chemical and Physical Behavior of Human Hair, 4th ed. Springer, Berlin, Heidelberg (2002).

6. Popescu, C. and Hocker, H. Hair - the most sophisticated biological composite material. R. Soc. Chem. 36, 1282-1291 (2007).

7. Dawber, R. Hair: its structure and response to cosmetic preparations. Clin. Dermatol. 14, 105-112 (1996).
8. Guo, X., Imhof, R.E. and De Rigal, J. Spectroscopic study of water-keratin interactions in Stratum Corneum. Anal. Sci. 17, 342 345 (2001)

9. Wang, B., Yang, W., McKittrick, J. and Meyers, M.A. Keratin: structure, mechanical properties, occurrence in biological organisms, and efforts at bioinspiration. Prog. Mater Sci. 76, 229-318 (2015).

10. Knowlton, J. and Pearce, S. Hair and Hair Products. In: Handbook of Cosmetic Science \& 
Technology (Knowlton, J. and Pearce, S. ed.), Elsevier Science, New York (1993).

11. McEwen, G.N. Jr Cosmetics: Controlled Efficacy Studies and Regulation. Springer-Verlag, Berlin Heidelberg (1999).

12. Schueller, R. and Romanowski, P. The Science of Reactive Hair Care Products. In: Beginning Cosmetic Chemistry. Cosmet. Toiletries 113, 39-44 (1998).

13. Draelos, Z.K. Cosmetics: an overview. Curr. Probl. Dermatol. 7, 45-64 (1995).

14. Evans, T. Fatigue testing of hair - A statistical approach to hair breakage. J. Cosmet. Sci. 60, 599-616 (2009).

15. Fernandes, M.M., Lima, C.F., Loureiro, A., Gomes, A.C. and Cavaco-Paulo, A. Keratinbased peptide: biological evaluation and strengthening properties on relaxed hair. Int. J. Cosmet. Sci. 34, 1-9 (2012).

16. Fernandes, M.M. and Cavaco-Paulo, A. Protein disulphide isomerase-mediated grafting of cysteine-containing peptides onto overbleached hair. Biocatal. Biotransform. 30, 10-19 (2012).

17. Ribeiro, A., Matamá, T., Cruz, C.F., Gomes, A.C. and Cavaco-Paulo, A.M. Potential of human $\gamma \mathrm{D}$-crystallin for hair damage repair: insights into the mechanical properties and biocompatibility. Int. J. Cosmet. Sci. $\mathbf{3 5}$, 458-466 (2013).

18. Oshimura, E., Abe, H. and Oota, R. Hair and amino acids: the interactions and the effects. J. Cosmet. Sci. 58, 347-357 (2007).

19. Villa, A.L.V., Aragão, M.R.S., Dos Santos, E.P. et al. Feather keratin hydrolysates obtained from microbial keratinases: effect on hair fiber. BMC Biotechnol. 13, 15 (2013).

20. Secchi, G. Role of protein in cosmetics. Clin. Dermatol. 26, 321-325 (2008).
21. Gray, J. Hair care and hair care products. Elsevier Sci. - Clin. Dermatol. 19, 227-236 (2001).

22. Gavazzoni Dias, M.F. Hair cosmetics: An overview. Int. J. Trichol. 7, 2 (2015).

23. Goodard, D.E. and Gruber, J.V., editors. Principles of Polymer Science and Technology in Cosmetics and Personal Care. Marcel Dekker, Inc., New York (1999).

24. Teglia, A. and Secchi, G. Proteins in cosmetics. In: Principles of Polymer Science and Technology in Cosmetic and Personal Care (E., Desmond Goddard and James V., Gruber eds.), pp. 404-477. Marcel Dekker, Inc., New York (1999).

25. Barba, C., Scott, S., Roddick-Lanzilotta, A. et al. Restoring important hair properties with wool keratin proteins and peptides. Fibers Polym. 11, 1055-1061 (2010).

26. Issei, Y. and Yoichi, K. Keratin hydrolyzate useful as hair fixatives. US4390525 (1983).

27. Yonghong, T. Fibroin hair conditioner and preparation method thereof. CN105662910 (2016).

28. Chen, L. Fibroin amino acid repair hair conditioner. CN103301041 (2015).

29. Deane, J.A. Hair cleansing conditioner. US 6723309 (2004).

30. Stepniewksi, G.J. and Lee, W.A. Hair treatment compositions. W02016160399 (2016).

31. Mingchuan, L. Wheat protein hair conditioner. CN103301040 (2015).

32. Hirata, Y., Kodama, Y. and Hirata, Y. Method of repairing or restoring damaged or imperfect hair. EP1369103 (2003).

33. Gumprecht, J.A. Treating hair with cosmetic formulations containing polypeptides. US4186188 (1980).
34. Shah, S.M. Heat-safe hair preparation and method of using same. EP0681826 (1994).

35. Vasconcelos, A., Freddi, G. and CavacoPaulo, A. Biodegradable materials based on silk fibroin and keratin. Biomacromol 9, 1299-1305 (2008).

36. Katoh, K., Shibayama, M., Tanabe, T. and Yamauchi, K. Preparation and physicochemical properties of compression-molded keratin films. Biomaterials 25, 2265-2272 (2004).

37. TRI Princeton Research Education Service. Humidity Resistance and Frizz Control [Internet]. (2016). Available at: http://www. triprinceton.org/humidity-resistance-andfrizz-contr, accessed April 2016.

38. Franbourg, A., Hallegot, P., Baltenneck, F., Toutain, C. and Leroy, F. Current research on ethnic hair. J. Am. Acad. Dermatol. $\quad \mathbf{4 8}(6, \quad$ Supplement), S115-S119 (2003).

39. Cruz, C.F., Fernandes, M.M., Gomes, A.C. et al. Keratins and lipids in ethnic hair. Int. J. Cosmet. Sci. 35, 244-249 (2013).

40. Coulombe, P., Tong, X., Mazzalupo, S., Wang, Z. and Wong, P. Great promises yet to be fulfilled: defining keratin intermediate filament function in vivo. Eur. J. Cell Biol. 83, 735-746 (2004).

41. Antunes, E., Cruz, C.F., Azoia, N.G. and Cavaco-Paulo, A. The effects of solvent composition on the affinity of a peptide towards hair keratin: experimental and molecular dynamics data. RSC Adv. 5, 12365-12371 (2015).

42. Barba, C., Martí, M., Roddick-Lanzilotta, A. et al. Effect of wool keratin proteins and peptides on hair water sorption kinetics. $J$. Therm. Anal. Calorim. 102, 43-48 (2010).

\section{Supporting Information}

Additional Supporting Information may be found in the online version of this article:

Figure S1 Images obtained by SEM of Asian and Caucasian hair sample (Asian virgin and Caucasian virgin); Caucasian hair samples after the climate control treatment formulations (base formulation plus peptide KP, base formulation without peptide, ethanolic formulation plus peptide KP, ethanolic formulation without peptide). 